\title{
Literary Places, Tourism and the Cultural Heritage Experience -the Case of Kumbakoanm
}

\author{
K. Selvakumar ${ }^{1} \&$ Dr. S.Thangaraju ${ }^{2}$ \\ ${ }^{1}$ Assistant Professor, Army Institute of Hotel ManagementE Catering Technology, Bangalore - \\ 560o77. Email: selva_siva@yahoo.co.in. \\ ${ }^{2}$ Associate Professor, Department of Indian Culture and Tourism, Government Arts College \\ (Autonomous), Kumbakonam, Tamilnadu.
}

\begin{abstract}
Purpose -Literary locations may be defined in diverse methods, however principally they gather that means from links with writers and the settings of their novels. Such locations magnetize vacationers and form part of the landscape of heritage tourism. Numerous key standards regarding heritage are applicable to literary places, and empirical research sanction a extra preponderant information in their pertinence how applicable problems of authenticity and conservation are to this revel in on area. Recognising the articulated aims, we explore how a cultural festival, and more specifically contemporary art, may positively influence the residents and visitors. paper examines, whether the city educate visitors about Indigenous cultures of the Tamils. The paper argues Further, aspects of infrastructure and hygiene are also reviewed.

Methodology -The research study includes both the primary and secondary data sources. The major data and information pertaining to the research study have been accumulated from the primary sources. The main sources of primary data were used is content and descriptive analyses of archival documents, contemporary literary works and inscriptions, in the Tamil language related to the social history of Tamils in classical period, personal visits to Kumbakonam and their observation.

Findings - The paper concludes by arguing that festivals' engagement with tourism needs to be carefully managed in the interests of promoting the socially sustaining function of festivals and of encouraging sustainable approaches to tourism development.

Originality/value -The paper explores spirituality and tourism in the context of kumabkonam city where there is very little formal research in this area. The paper serves as a stepping stone towards future research on overlooked religious site and their management
\end{abstract}

Keywords: Tourism, Culture, heritage ,Religion, Temple, Mahamagam

\section{Introduction}

Travelling from part to part, visiting several notable places is nothing new to Indians. kshetradana, TirthaYatra are some of the names to such enjoyable peregrinations. As a matter of fact, our sacred scriptures make it mandatory for each of us, that we should at least once in our life, visit some sacred part, and bathe in holy pools. In the great Epic Mahabharata, there is separate sarkam(chapter) tiled Arjuna's tritha yatra sarkam, wherein all the pilgrimages wanderings of arjuna is vividly described. It In Hindu to visit Mount Kailas, have a Darshana of Visvanada at kasi(Benares), bring the holy ganga water from that place to Rameswaram the southern extremity and perform ablutions with that water to the god there. The bond of national integration was thus intensified.

This ancient Kshetradana has evolved into Tourism in modern days and it has become an important industry, uplifting the national economy. Business minded people, sportsmen, art lovers, historian all have joined the band of religious pilgrims. Above all foreigners visit India in (c) AesthetixMS 2016. This Open Access article is published under a Creative Commons Attribution Non-Commercial 4.0 International License (http://creativecommons.org/licenses/by-nc/4.o/), which permits non-commercial re-use, distribution, and reproduction in any medium, provided the original work is properly cited. For citation use the DOI. For commercial re-use, please contact editor@chitrolekha.com 
large numbers. In India, temples are the mirrors that reflect the cultural evolution of the people from remote ages, and no one can understand the people without a study of the temple.The city now known as Kumbakonam (kumbha-pot) was known generally in the Devram hymns as kudamukku(kudam-pot, mukku-nose). In the songs of St.Appar and St.Tiru Jnanasambandhar $\left(7^{\text {th }}\right.$ century A.D.,) this name is the one by which the city is referred to in the chola inscriptions. The presiding deity of the kudamukku temple is Kumbhesvarar who is also the presiding deity for the mahamagham festival. The city kumbhakoanm takes its names from this aspect, kumbhesvara of siva.

Two other Siva temples have also hymns sung on them by the Nayanmr and they are known as Kudandaik- Kilkkottam and Kudandaik karonam. The nagesvara temple is the most superb creation of chola art. It is possible that it was constructed by aditta chola (871-907 C.E.) who, the Sanskrit inscription say, studded the banks of the kaveri with thousand temples to lord Siva. . Historically, they have marked their local calendars with social events that celebrated important historical, religious and cultural events commemorating birth, marriage, death, the harvest, and salvation from peril (UNESCO, 2004). Kumbakoanm is centre round which we have five shrines called the pancha-krosa sthalas, shrines which are situated at a distance of five kroasa (about 11 miles). The shrines are Tirvdiaimarudur, Tirunagesvaram, Darsuram, swamimalai and pataivanam(karuppur) But unfortunately, proper literature embracing all aspects of our culture and history are not available in sufficient numbers, with the result that they are left to the mercy of ill informed men, who do not enlighten properly. And they return to their country with poor opinion of our land.

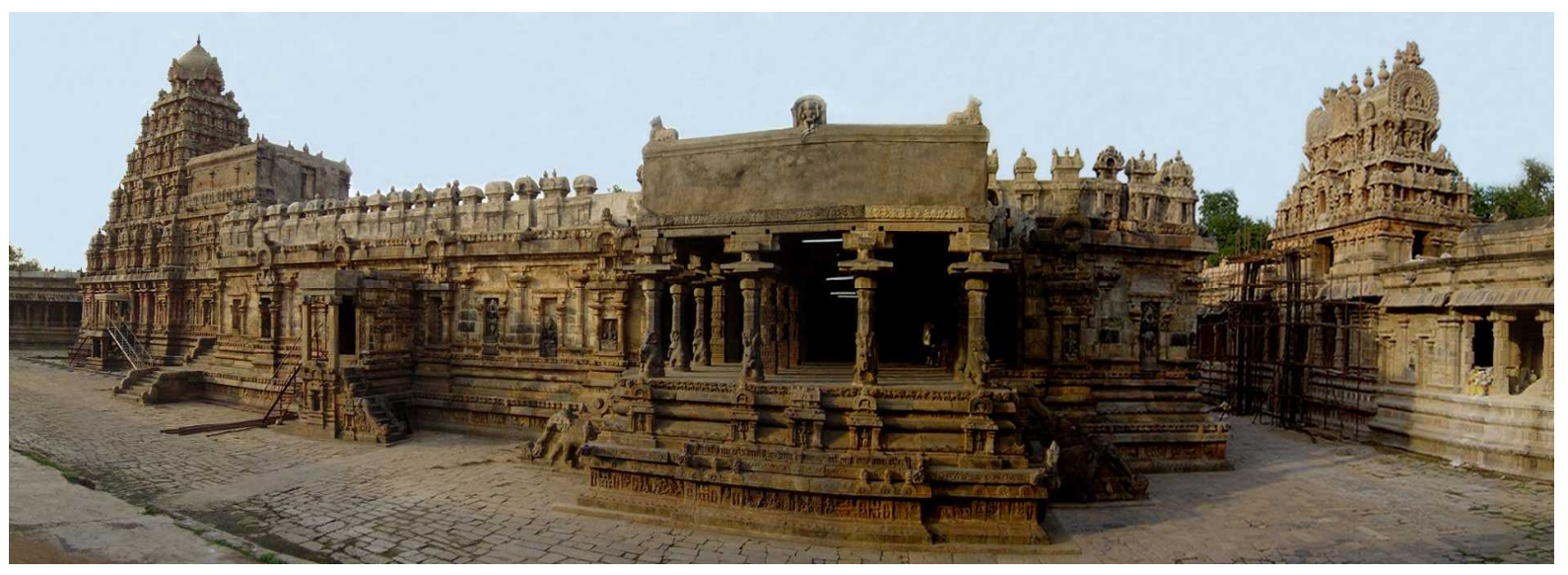

Figure 1. Darasuram Airavatesvara Temple Great Living Chola Temple( UNESCO World Heritage Site)

\section{Mahamagam Festival and quality of life}

Pleasure-pain are two qualities that every human being is subject to, but do such qualities really exist? No! They are only illusions created by the turbulence of the mind. A short story from yoga vashistam will not be out of place here. King janaka steeped in luxury one day dream that he became a victim of a famine that ravaged mithila. All his subjects perished of starvation and janaka too experienced the same agony. He was wildly running in search of food where he saw a corpse clutching a loaf of bread. Janaka quickly seized it only to be snatched by a crow. And in utter dismay be cried loudly that his attendants poured in. Janaka was baffled and summoned his court pundits. he posed them a question which is true. King janaka in luxury or janaka in penury? Ashta-vakra, a scholar enlightened the king. Both are true as well as false. In that relative state it 
is true. But when one passes in to the other state, the happenings of the previous state became false. Events in our life are true in that state only, and when we transcend in to higher sate, the life occurrence become illusion. That state in which there is neither pleasure nor pain is the liberated state. Moksha, PariNirvana, Mukti, samdhi, veedu, are all various names indicate the state.

But how to attain that state? Since all the miseries are the products of the mind, liberation ha to be achieved only though the mind. A thorn has to be removed by thorn and then thrown. The turbulent mind has to be stilled first before one can expect peace to descend. The supreme truth is formless, inexpressible and unfathomable. It can only be experienced by individuals. But such abstract knowledge cannot be digested easily by common people. A peg is essential to hang the whirlpool of activity and temples, sacred tanks, sacred rivers, are the pegs.A peaceful atmosphere, a fervent belief in its Omnipotence and a miracle occurs. Effortlessly, a person attains peace. The calm unruffled mind is conducive to experience the supreme bliss. Our ancient siddars and sages in their wisdom and insight have shown that worship in temples, bathing in the sacred tanks gradually leads one to higher realms.

One pointedness of mind has to be practised to concentrating all attentions on one object only to transcend that stage also. Bakthi or devotion towards the supreme symbolised by idols enshrined in temples, plays an important part in our lives. Kings who erected magnificent edifices as house of gods have given their reasons as due to bakthi and for welfare of subject. The very lives of the people centred round the temple in that village and more time was spent there than in their houses. Bathing in the sacred tank, worshipping thrice every day, attending festivals, meditatingall these snatch away a major portion of their time. In short a spiritual awakening and uplift blossomed though the shrines.

\section{MAHAMAGAM FESTIVAL}

\section{History}

There are three aspects to every festival in the land. The first is the ritualistic aspect- the various steps of its celebration, whether it be in the home or in the temple, the performance of a puja, preliminary arrangement etc.

The second is the legend aspect- the ancient stories which had grown round it, which had caused the origin of the festival, the benefits attained by some who celebrated it early in the history of the society, and so on. The third is the philosophical or esoteric aspect which gives significance to the celebration and which has kept it alive through so many centuries. In many, the philosophical aspects may not be fully explicit, but a social significance may be apparent.

The festivals seem to constitute in a sense the eternal religion of India, particularly tamilnadu. We need not know when the celebration of festivals by society or the state started. Saint tirujanasambandhar mentions a series of monthly festivals fro the twelve months which were popular in his day (the seventh century). Most of them continue to this day almost unchanged both in the manner of celebration and in their significance. Festivals are the outward social expression. Of the communal joy of the people and by the celebration in the present, hand it down to the future generation. Festivals, mostly conservative, do not lend themselves easily to changes but continue to be rigid and the very rigidity opens up as it were a window for us to have a peep in to the past. The greatest south Indian festival is probably the Mahamagham festival at kumbakonam in the tanjavur district on the southern bank of the river kaveri, occurring once in 
twelve years. The last festival occurred on the 16 th feb 2016 on the masi maham day the festival attacted about 15 lakhs of people from all over india and abroad. This festival is similar to the Kumbha mela of Prayag and Pushkrram of Andhra, but unlike those two which are celebrated on rivers, the tamilnadu festival is celebrated on a tank, known alwys as the Maha magham tank

The antiquity of the Mahamagam is reasoned from the structural and epigraphical examples. The roof of the Gangatirtha mandapam conveys the sculptural representation of Tulapurushardava. It is trusted that Govinda Dikshitar subjected himself to the occasion and gave the gold to the building of the sixteen mandapas. The visit of Krishandevaraya amid 1445 is recorded in an engraving in the gopuram of Nagalpuram, a town in Chengalpattu locale. That Krishnadevaraya went to the occasion is likewise recorded in the engraving found in the Shiva sanctuary in Kuthalam

\section{Literary Mention}

Bhavishya Purana notices the significance of Mahamagam and the significance of the celebration as a story of Shiva to every single divine deitie as under:

Let every one of you this very day go to Kumbakonam, a spot dear to me and to Vishnu and bathe there is the nectar full tank made by the bearings of the Parabrahman. Do bathe in the vicinity of Kumbesvara in Vrishaba lagna on this Mahamagam day, the full-moon day consolidated with Mahga star with Jupiter in the indication of Leo. Subsequently you will dispose of all your amassed sins and recover energy to wipe off the wrongdoings of others Sekkizhar, saint author of Periyapuranam notes the holy rivers as

\section{பூமருவும் கங்கை முதல் புனிதமாம் பெருந்தீர்த்தம் மாமகந்தான் ஆடுவதற்கு வந்து வழி படுங்கோவில்}

Importance a dunk in the sacred tank on the Mahamagam day is proportionate to plunge in every single heavenly waterway and prompts common thriving. Appear, the seventh century holy person writer says the inconspicuous vicinity of sacred waterways like the Ganges in the Mahamagam tank in Tiruthandakam

தாவிமுதற் காவிரிநல் யமுனை கங்கை

சரஸ்வதிபொற் றாமரைபுட் கரணி தெண்ணீர்க்

கோவியோடு குமரிவரு தீர்த்தஞ் சூழ்ந்த

குடந்தைக்கீழ் கோட்டத்தெங் கூத்தனாரே"

\section{Structure of the Tank}

On the banks of the Mahamagam tank, there are 16 small mandapams ( 4 in the north, 3 in the west, 3 in the south, 2 in the east and 1 each in the diagonals) housing a Lingam each. There are 20 theerthams in the tank \& bathing in the waters of each theertham rids of a specific sin \& bestows a specific blessing. The tank is spread over 20 acres and is not a proper rectangle. The north and south banks are a little curved in the centre and from an aerial view looks like pot. There are 16 temples all around it, four in the north, three in the south, three in the west,two in the east, and one in the corners. All are lingams. hence they are called shodasa (16) mahalingas. 


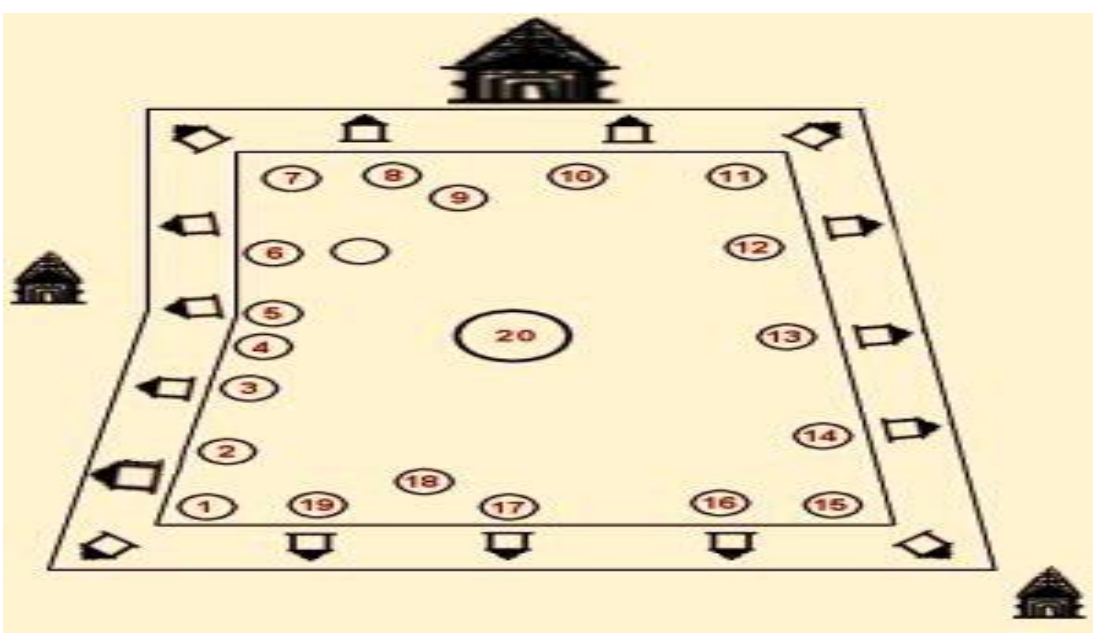

Figure 2 Structure of the Tank

\section{Mahamagam festival and its significance}

If there is a tank held to be more sacred than Ganges, it's only the mahamagam tank at kumbakonam. As kumbamelas are celebrated in rivers, mahamagam is celebrated in this tank. The mahamagam occurs once in 12 years. In kodiakanal a shrub called kurinji flowers only once in 12 years. Scholars opine that these occurrences once in 12 years are due to planetary effect. They have also noted that sun-spots in large numbers occurrences in 11 years, and that they are responsible for certain events in earth. Great revolution such as French revolution, Russian revolution, spin and Hungarian revolution took palce only when the sn-sopts appeared in large numbers.

We all know that tides are caused by planets, and the water-balance of our body are equalised at that time. Sun spots cause earthquakes too. Further it has been found that Jupiter that revolves around sun taking 12 years, causes a large number of sunspots, when it nears the sun.

During the month Masi, the sun is in simha Rasi(leo). In that month the star maga happens on a full moon day. It is also generally accepted that full moon and new moon days intensify sickness, and death. In villages when a doctor is asked about the condition of a critical patient, he will reply that he can give a correct position only after the new moon day. And protect oneself from sickness we are advised to bathe in sacred tanks and rivers.

Once in 12 years, with sun in simha rasi Jupiter(guru) dominant the effect of sun, Jupiter and moon, changes occur in the body and earth. And to prevent any calamity, bathing sacred tanks have been practiced. for all movements in the universe, magnetic force and attraction is essential. During certain periods when sunspots are increased numbers, sickness results due to the nature of the prevailing soil (earth). In places where magnesium is prevalent in greater quantities, the magnetic force is stored. When that chemical mixes with water in that place the ill-effects are at a low-level. When puranas declare that one gets rid of the sin by bathing in this places, it means that they replace the lost magnetic force by bathing in waters rich in that energy. Hence this festival once in 12 years is more of science than a mere ritual.

Purify Your Karma Through The Holy Water Dip Ritual On the auspicious day of maham Magam icons of divinities are taken from their blessed sanctums in a parade for a sacred plunge in the stream. Offering petitions to God and scrubbing down in blessed streams like Ganges, Cauvery 
and others is accepted to be a heavenly custom to wash away the karma in oneself. pepoles have the act of washing up in the wells of Kumbakonam - Maha Maham sanctuary tank, to wipe out the heaviest of their karmic stuff on Masi Magam. It additionally introduces a unique opportunity to get karmic mediation from the heavenly beings and ancestors.

Water: The Medium the Universe Uses to Communicate With Us Our cells contain 75 to 90\% water. The cells have the ability to store and share information in particular photons called biophotons. They are the weak electromagnetic waves in the visible range of the light spectrum that our cells emit to control vital processes. Consider This...The water in the Kumbakkonam Tank is said to be a blend of water from the Sacred Ganges, Yamuna, Saraswati, Sarayu, Godavari,Mahanadi, Narmada and Kaveri. The water has been held as holy and heavenly for thousands and a large number of year through their extremely method for creation and by supplications to God and ceremonies of individuals since their beginnings. No matter their physical virtue do to contamination and so on, magically or profoundly they are unadulterated and exceedingly, Divinely charge Aham means sin. Ma means will not approach. So the term mahamaham means a place where no sin will approach. It will also mean that (maha) big sins will be removed.

\section{Contemporary visitor management issues at historic city}

History, culture and religion constitute significant elements of tourism. Millions of tourists in any one year visit historic centres, temples and places of unique cultural value. Many of these major cultural attractions are located in close proximity to, or within, large urban centres. In general terms, this could be considered 'mass tourism', which reflects the high numbers of visitors to cultural and heritage sites; often for little more than a short stay or brief excursion. This pattern of visitation creates pressures that need to be managed effectively, taking into consideration the visitor experience and the capacity of local systems to support such pressures (Garrod and Fyall, 2000). These two areas are explored below. The constraints of space preclude detailed analysis of the varied forms of cultural tourism and associated sites; to an extent this is well illustrated by the cases encompassed within this text. The approach taken is to focus more on those generic aspects of operational management that may vary according to the type, or more appropriately perhaps, the site, of cultural attraction. In the process, the aim is to highlight key issues and potential management responses, which complement or are developed in the case studies that follow in this section.

\section{Lack of political will}

A lack of political will is perhaps the most vivid problem facing throughout the india, both in developed and developing countries. The most lucid example of this is a lack of legislation and law enforcement - a problem endemic throughout the region.

\section{Lack of information for tourists}

Information plays a consequential role to magnetize the attention and interest of tourists to visit a destination. It is desirable if tourist-cordial information relating to the history of state is provided. The Tourism Development Division or peregrinate agents should strive to publish a brochure concretely about the cultural heritage of the state, which should be simple and clear to understand and practical for tourists. This brochure should include an adumbration map of state together with information relating to the history, places of interest, activities that can be done by tourists, the expedient to visit, and the materials that can be obtained as a keepsake in the state. 


\section{Lack of facilities and services for tourists}

It is important that tourists are satisfied with their visit to a destination. Basic needs such as tourist lodges or hotels, resting huts, clean toilets and eating places, as well as safe jetties should be available to convince tourists to visit Kumbakoanm. Apart from the state of infrastructure, tourist services such as guides who are knowledgeable about town need to be provided as well. It is observed that local people still shy away from the tourism industry in the country such as providing guide services. Travel agents still hire outsiders to provide guide services to the tourists. Professions such as tourist guides can be done on a part-time basis, which can bring additional income to the individuals.

\section{Tourism and city}

One of the best festivities in India, which pulls in huge hordes of travelers from all parts of the nation, will be performed in Kumbakonam, in the sacred Mahamaham Tank. Kumbakonam town is interestingly situated inside tamilnadu and future tourism advancement ought to expand upon this prime area. It pulls in more than 500,00o guests year in light of the fact that it is at the heart of one of the Dravidian civilisation most vital tourism resources.The tourism part has since quite a while ago perceived the estimation of the journey tourism. The town is midway found and offers different social and notable (one of Tamils protected antiquated and medieval destinations) tourism advancement opportunities. Its way of life and legacy structural engineering, which originate from the blend of Dravidian conventions, gives an abundance of interpretive and touring encounters

This mahamahm festival will bring a mixed bag of advantages to as a city additionally as a visitor destination:

- It gives off-season advantages to the economy;

- It will expand interest of nearby business: inn bookings, sustenance eateries, transportation;

- It can recommend travellers to stay for a more extended time at the destination;

- It can strengthen the destination's picture and help in advancement, situating and marking of the destination;

- It serves to convey the destination's mindfulness and construct brand value.

The long haul focal points of leading this celebration may be alluded as change in foundation, alluring speculation by enormous organizations, personal satisfaction for local people and astonishing knowledge for explorers, destination's image building and an increased the value of the city's character.

Keeping in mind the end goal to understand the advantages of game occasion tourism in an inexorably aggressive commercial center, a dream and arrangement is needed for the advancement of the occasion and destination. Tourism division must distinguish the best target business sector portions, settle on proper systems and produce various vital associations. A lot of advertising exploration is important to better comprehend occasion visitor intentions and to bundle and advance the occasion viably.

\section{Discussion and further perspectives}

- Language barriers were the most commonly faced by the "North-Indians" followed by the foreigners. Most of the "North-Indians" do not understand the local language very well. 
Though the sign boards are provided in English and Tamil a desideratum for English/Hindi sign boards, English/Hindi verbalizing guides are expected.

- The Non-availability of hygienic food as noted above was an eminent quandary faced by the tourists. Foreigners perceived it to be a major quandary. Beggars were a major quandary.

- Sanitation facilities were additionally among the highest quandaries just like the jams but with unequal replications. Non-availability of peregrinate information was withal a prominent issue for many of the tourists especially for the foreigners followed by the north Indians

- Lack of Protection and preservation of identifying heritage resources including the archaeological sites spread around the temple

- Inadequate provision of Health, recreation facilities, open spaces and other amenities for pilgrimages

- Poor traffic management and inadequate provision for parking lots, particularly around temple areas.

- Lack of singe boards.

- Too much litter and garbage at the pilgrimage sites, roads and train accommodations needed to be amended, clean toilets were destitute, and that touts and beggars were too truculent and spoiled the experience at the tourist sites.

- Strengthening of connecting link road in and around kumbakonam .

- Encourage companies to provide information to tourists on cultural activities that subsist in the destination, and to establish cognizance programs for the care of heritage and reverence for local customs.

\section{Conclusions}

Cultural festivals are held in almost every city in the world. These events represent a major attraction for residents and tourists alike and have significant economic implica- tions for hotels, restaurants and retailers. It is therefore important for presenters of festivals to understand and manage the processes by which consumers form images of festivals, because attitudes and the desire to participate in festi- val activities partly depend on these consumer image. It is required from the Ministry of tourism and affiliate institutions to provide advertising programs on historical and religious sites in the region, plus to market it publically at home and abroad. It is required from the Ministry of tourism and affiliate institutions to sponsor religious activities and festivals, and tourism programs and its diversity.

\section{References}

Action Plan for the Provision of Basic Amenities and Infrastructure Development Works in Kumbakonam. Bhatt, S.C. (Ed.). (1997). The Encyclopaedic District Gazetteers of India, Vol. 2, Gyan Publishing House, New Delhi.

F.R. Hemingway (2000). Tanjore Gazetteer, Vol. I, Cosmo Publications, India.

Garrod, B. and Fyall, A. (2000). Managing heritage tourism. Annals of Tourism Research 27(3): 682-706

K.A.Nilakanta Sastri and N. Venkataramayya, Further of Sources of Vijayanagara History, University of Madras, 1946.

Kaur, S. (2008), "Connected by air, Golden Temple turns attractive destination for foreign tourists", available at: www.financialexpress.com/news/Connected-by-air-Golden-Temple- turns-attractivedestination-for-foreign-tourists/343463/ (accessed July 5). 
45 | Literary Places, Tourism and the Cultural Heritage Experience -the Case of Kumbakoanm

Kumar, V. (2010), "8 million tourists visit Vaishno Devi Shrine in J\&K”, January 29, available at: www.groundreport.com/World/8-million-tourists-visit-Vaishno-Devi-Shrine-in-J-_2/ 2916854 (accessed July 5).

Kumbakonam, P. Carl. (1998). Art, Architecture and Urbanism, Space: Ritual and Meaning in a Sacred Royal City of South India, Cambridge University, U.K.,.Town for the Mahamagham Festival, 2004

Nagaswami, P. (1980). Art and Culture of Tamil Nadu, Sundeep Prakashan, Delhi..

Palmer, R. (2004). European Capitals/Cities of Culture: Study on the European Cities and Capitals of Culture and the European Cultural Months (1995-2004) (parts I and II). Brussels: European Commission/Palmer/Rae Associates.

Rev. H. Hevas and S.J. Ma. (1929). Beginnings of Vijayanagara History. Indian Historical Research Institute, Bombay.

Waterman, S. (1998) Carnival for elites: The cultural politics of arts festivals. Progress in Human Geography $22(1), 54-74$. 